\title{
EXPATRIATES AND INTERNATIONAL CAREER MANAGEMENT: CORPORATE AND SPORTING CONTEXT
}

\author{
Ivan Wallan Tertuliano ${ }^{1}$ \\ Adventist University, São Paulo/SP, Brazil \\ Vivian de Oliveira ${ }^{2}$ \\ University Center FIEO, Osasco/SP, Brazil \\ Bruna Alves Santana ${ }^{3}$ \\ Adventist University, São Paulo/SP, Brazil
}

\begin{abstract}
Globalization makes expatriation an increasingly present reality, whether in the lives of employees of multinational companies or athletes. Therefore, the objective of this essay was to conceptuate the International Human Resources Management (IHRM) and to point out the relationship of such phenomenon with the career management conducted by the person participating in this process of "expatriation", both in corporate and sports contexts. For this, it was based on the methodological design of a qualitative research on the perspective of documental analysis. As the main reflections of this essay, we emphasize that, although it is considered fundamental, the IHRM is better developed in companies, while in sports clubs this is a secondary concern. It is also noteworthy the importance of athletes and expatriate employees to undergo a process of preparation, both from the psychological and social, economic and cultural point of view, so that the changes are faced in the best possible way.

Keywords: International human resources management; Expatriation; People management; Human resources Administration.
\end{abstract}

\section{INTRODUCTION}

Expatriation is a phenomenon that grows every day, and most expatriates justify the exchange of country for reasons such as the search for better living conditions, work in foreign companies, the study of another language, improvement of salaries etc. (Baruch, Dickmann, Altman, \& Bournois, 2013; Carvalho, Santos, \& Brandão, 2015; Ferreira, 2015; Gallon, Scheffer, \& Bitencourt, 2013; Nardi, 2015). According to Carvalho (2016), this phenomenon is a consequence of the influence of globalization and internationalization. Globalization is a phenomenon that affects the whole world, but occurs in different ways according to the region or the observed aspect, leading to economic, cultural, technological and political consequences (Tertuliano, Montiel, Deutsch, \& Machado, 2019).

\footnotetext{
${ }^{1}$ Corresponding author. ivanwallan@gmail.com

2 vivian_oliveira58@hotmail.com

${ }^{3}$ Adventist University, São Paulo/SP, Brazil, Brasil. brunnasantna@gmail.com
} 
In sporting context, the reality is no different. In the last 15 years, it has increased the number of athletes who change teams or even nations in search of new goals or life improvement (Tertuliano, Oliveira, Pavlović, \& Machado, 2018; Tertuliano, 2018; Tertuliano, Machado, Deustch, Montiel, \& Bartholomeu, 2018; Tertuliano, Machado, Oliveira, et al., 2018; Tertuliano et al., 2019). The expatriation of athletes has existed since the first decades of the 20th century, but has accelerated after 1996, due to changes in European legislation for these issues, especially for football athletes (Tertuliano, 2018; Tertuliano, Machado, Oliveira, et al., 2018). Among the reasons, in the sporting context, wage improvement is pointed out as paramount for athletes to accept expatriation (Pontes, Ribeiro, Garcia, \& Pereira, 2018; Sebben, 2009; Tertuliano et al., 2018; Tertuliano, 2016; Tertuliano, Machado, Deustch, et al., 2018; Tertuliano et al., 2019; Tiesler, 2016).

In view of this new reality, the so-called international Human Resources Management (IHRM) emerges, which seeks to plan, develop and also implement new and better approaches for the management of people who are in different contexts and realities International (Altman \& Baruch, 2012; Bjerregaard, 2014; S. M. S. Carvalho, 2016; Mach \& Baruch, 2015). Thus, the objective of the present essay was to conceptuate the International Human Resources Management (IHRM) and to point out the relationship of such phenomenon with the career management conducted by the person participating in this process of "expatriation", both in the corporate context and in the sporting contexts.

In order to present and propose academic-professional postures, this essay aimed to bring a direction, in which classical and contemporary studies were used to weave on the theme providing a greater radius of reflection. Thus, it was based on the methodological design of a qualitative research on the perspective of documentary analysis (Marconi \& Lakatos, 2017).

\section{EXPATRIATION - INTERNATIONAL HUMAN RESOURCES MANAGEMENT (IHRM)}

The diversity of employees that exist in multinational companies implies the need for a Human Resources Management (HRM) appropriate to this reality, with specific concerns, varying according to the country and the internationalization phase in which the Company is (Ivancevich, 2008).

Thus, Dowling et al. (2008) point out the importance of the expatriate to have mastery of the local language, control and direct supervision, an agent that helps him socialize and transpose the culture, construction of networks of contact, transfer of competences and 
Knowledge and influence with local agents. For this, Black \& Mendenhall (1990) point to the need for training offered by the companies, before the expatriation and the accompaniment of the adaptation of the collaborator to the new country, as factors for improving the performance at work as well as the Development of new skills for the expatriate.

From this perspective, expatriates who receive training are more easily adapted to the new country and workplace, presenting better performances in the activities. Thus, the concept of International Human Resources Management (IHRM) emerged, which is understood as a process of definition, planning, development and implementation of the best policies and practices of people management in different international contexts (S. M. S. Carvalho, 2016).

Thus, the IHRM is a necessary tool for the expatriation process (Pereira \& Saboia, 2015). The IHRM is concerned about the adaptation of the collaborator to the new country, through basic guidance services, to more complex services, such as housing assistance, tax debts, etc. This is because by equating its internationalization, the company must review its management of people, transforming its local perspective in international (S. M. S. Carvalho, 2016).

The IHRM presents several challenges, mainly in recruitment and selection, as well as in the remuneration systems, in the training and development of expatriates, in their career management, in the social responsibilities inherent to the process and Labor Relations and Leadership (Hill, 2005). This makes it a complex tool, especially in the face of six factors (Riesenberger, Knight, \& Cavusgil, 2010), that are guiding for managers in the planning, selection, training, employability and international assessment of human resources (Pereira \& Saboia, 2015). The factors pointed out by Riesenberger et al. (2010) are:

1) New Human resources responsibilities.

2) The need for a broader international perspective on remuneration policy.

3) Greater involvement in the lives of employees.

4) Managing the combination of expatriates and local employees.

5) Greater exposure to risk factors.

6) External influences of government and culture.

Chien and Mclean (2011) suggest that expatriate professionals feel the need to receive organizational training on the culture of the destination country, on the construction of new relationships, on business policies and also on legal issues of the new place of residence. Based on this, the literature points to the need for IHRM strategies that contribute to the expatriation process. Thus, Wentland (2003) cites six strategies that can contribute to the IHRM: 
1) Negotiation with the expatriate.

2) Salary adequacy, because the expatriate should not suffer financial loss because he accepted an international migration (IM).

3) Offering a compensation package that conforms to what native/local employees receive.

4) Offering an additional for extra expenses.

5) Cafeteria, namely some benefits such as company car, club membership titles, insurance, home provided by the company and educational fees.

6) Regional systems: Applies when the expatriate makes an agreement to work within a particular region in the world. IHRM:

Already Shen \& Kram (2011) signalize Four Strategies for the

1) Offering interaction with people who have the potential to assume the role of manager.

2) Promotion of trainings to create contacts that serve for their development, both professional and personal; Transforming Individual tacit knowledge (individual knowledge, without technical and/or scientific organization) into organizational knowledge (knowledge that can be transmitted by the company as a standard, manual), so that it can be shared throughout the organization.

3) Facilitation of virtual communication between expatriates and repatriates from different countries for the formation of a group with the objective of clarifying doubts and exchanging experiences on how to live in a particular country, how to exercise their work, as well as defining which social activities can be undertaken.

4) Recognition and reward of individuals who can help expatriates, both at the time of change of thirst and on their return.

The foregoing allows the Human Resources manager (HR) to establish an incentive plan for expatriate employee, training and preparation. Thus, managers should follow 4 perspectives, pointed out by Carvalho (2016). The first perspective is called an ethnocentric perspective, which is based on the application of HR policies of the matrix in all subsidiaries, with minimal adaptations. The second perspective is the polycentric perspective, in which the subsidiaries gain autonomy to develop adequate HR systems with their reality, with support from the matrix. 
The third perspective is the geocentric perspective, in which the improvements in HR practices apply, regardless of whether it is from the matrix or from another company (even the subsidiary), giving the occupation of the important positions of the subsidiary to talented people, in any part of the world. Finally, the regiocentric perspective, which has a similar approach to the geocentric, but with a restricted focus to a particular region, that is, the important positions of the subsidiary are occupied by people from a specific region.

In the sports arena, the responsibility for the expatriation and repatriation processes of players, especially in football, falls on the player, the entrepreneur and the club (Machado, 2013). In this perspective, some studies were conducted, relating the difficulties of players's adaptation in the expatriation and repatriation (Machado, 2013; Rial, 2008; Rodrigues, 2010; Silva, Rigo, \& Freitas, 2012) and some studies, of a theoretical nature, discussed the phenomenon of expatriation with the globalization (Alvito, 2006; Damo, 2007; Rial, 2003). Discussions about expatriation and repatriation processes in companies can be the same as those surrounding players in the sporting context (Machado, 2013).

The big question is that due to the financial return to those involved in the transfer (player, club and entrepreneur), and this discussion becomes a secondary discussion in the sport. However, similar to a collaborator who leaves the country, the player will go abroad with an overload of tasks and responsibilities as large as those of a Brazilian professional who has just assumed the presidency of an American multinational in South Korea (Sebben, 2009).

Machado (2013) points to a change in the management practices of the clubs, bringing them the approximation of management models more current and similar to multinational companies. Even so, the policies of the clubs aim at the sale of players, without any management of the player's career, because the clubs assume that the player has a contractual relationship, investment, generating a gap between the club and the player.

This gap is, in parts, supplied by the entrepreneur, who often acts on the aspects of the personal life and economic interests of the players. In this way, it is evident that the club does not have a strategic vision related to the processes of expatriation and repatriation of players, and that the entrepreneur, empirically (model of trial and error) assumes the role of preparation of the expatriation process, which urgently makes the need for IHRM policies in sport (Machado, 2013; Sebben, 2009).

To resume, the IHRM should assume a facilitating and supportive role in pursuing the company's objectives by promoting the development of its employees (Rego \& Cunha, 2009; Zhou, 2015), Through the implementation of activities and strategies that overcome the specific 
challenges of HRM in the global world and that these strategic can be adopted in the sport. These practices relate to preparation for international migration and for return, rewards systems, good working conditions, hierarchies support and career management programs.

In sport, decision making on expatriation is very empirical, which contributes to the failure of the process. In this way, the management of expatriates plays an important role, given the high cost of international migrations, with regard to turnover (average rate between admissions and disconnections in relation to the average effective in an undertaking), the family, the management of the career of the expatriate and the difficulties of adjustment (S. M. S. Carvalho, 2016; Rego \& Cunha, 2009; Zhou, 2015).

\section{EXPATRIATION - CAREER MANAGEMENT}

The management of expatriates has a close relationship with career management, as expatriation, regardless of their going, by the company's will or willingly, refers to the development of an international career (Araujo, Teixeira, Cruz, \& Malini, 2012). Several authors try to define the concept of career, but there is no clear definition of the concept, since the term was studied in different theoretical perspectives (Santos, 2011). In the sociological perspective, career means the course of a professional life (Moore, Gunz, \& Hall, 2007). In the business perspective, career is a sequence of work-related experiences, experienced by the person throughout life (Arthur, Hall, \& Lawrence, 1989; Arthur, Khapova, \& Wilderom, 2005; Carvalho, 2016), or rather, a set of positions occupied by a person throughout their professional life, always providing retribution, financial or not (Alis, Des Horts, Chevalier, Fabi, \& Peretti, 2014).

Ivancevich (2008) associates career with the exercise of functions within business structures and other factors such as remuneration, prestige, power and prospects not linked to a gainful activity or company, such as volunteer workers or housewives. In summary, career can be understood as a set of activities undertaken by a person to initiate, guide and follow their professional path, within or outside the organization, in order to fully develop their skills, capacities and skills (Alis et al., 2014; S. M. S. Carvalho, 2016).

The career can be understood as internships, which led to the emergence of different models, such as the protean career, career boundaryless and intelligent career. For Santos (2011), the career, for years, was assumed as internships, determining the career as an evolutionary process. Super (1957) assumes that the career goes through different stages, ranging from the interaction between the self-concept, the professional 
occupation chosen and the exerted. In this model, and occurs through the stages of exploration, establishment, maintenance and overcoming.

Subsequently, Super (1990) recognizes weaknesses in its model, because not all stages can represent career development in all individuals, assuming that the career is the evolution, throughout life, of temporal, spatial dimensions and individual involvement with the role played. Following the line of internships, Schein (1978) proposes the model of careers based on development in an organizational context, considering career as a process of mutual influence between the company and its employees over time.

With a look at the human being, Levinson (1986) proposes the career model based on the stages of development of individuals, throughout life, including not only the professional, but the individual and family, as well. Derr (1986) proposes a different career model, highlighting the importance of the concept of internal career - refers to individual motives, values and talents. Thus, for Derr (1986), the internal career develops based on training and professional experiences acquired over time.

However, countless criticisms are conducted on the aforementioned career models (Santos, 2011), mainly taking into account the social and economic changes that have occurred in recent decades, resulting in the emergence of models emerging career (S. M. S. Carvalho, 2016). For Hall (1996), the career in the 21th century must be managed by the individual, commanding it according to their values, which the author called a protean career. In the protean career, unlike the traditional career, there is no pact with the organization, but rather a relationship between the individual and his work. In this way, the career is self-managed and reinvented by the individual, characterizing a development based on continuous learning.

Another concept of career, similar to that of a protean career is that of boundaryless career (Arthur \& Rousseau, 1996). In this model, life-long mobility is emphasized, that is, the individual develops a set of interesting competencies for the labor market, increasing his employability, thus declining on the individual the responsibility for his career .

Assuming that knowledge directs the company, the concept of intelligent careers emerges (Arthur, Claman, \& DeFillippi, 1995). In this career model, development occurs through three competencies, which are assumed to be transversal: To know why, to know how and to know who. These competencies relate to interpersonal relationships and important relationship networks for work (DeFillippi \& Arthur, 1994).

In synthesis, up to 1990, career meant the permanence of the person in the same company throughout his life. However, due to the globalization and the rapid changes and adaptations that the companies suffered, this became incompatible, which generated the end of long-lasting careers and 
the emergence, in the decade of 1990, of the concept of cyclical career, model opposite the traditional, which was in force up to 1990 (S. M. S. Carvalho, 2016).

For Chanlat (1995), the traditional career declined due to the growing presence of women in the labour market, the increase in employee qualifications, the affirmation of worker's rights, the globalization of the economy, the competitiveness of companies, the need for constant changes in companies and greater flexibility at work. These changes led to the emergence of two concepts: subjective career and objective career (Santos, 2011).

The subjective career, also called internal, is built by the employees according to their values, aspirations and expectations, being much more important than the occupied function. In turn, the objective career, also called external, is the performance of employees in functions framed in the company, as well as expected progression in it. Arthur (2008) goes further, defending that one must integrate the two concepts so that we have an understanding of the career in a full way, as they complement each other. In order to organize career concepts, Kanter (1989) suggests the classification of careers in three possibilities:

1) Bureaucratic career - a vertical career that occurs through several levels of an organizational structure.

2) Professional career - performance of an activity within the organization, considering the professional progression the assignment of more demanding and challenging tasks.

3) Entrepreneurial career - creation of small businesses or autonomous work. In the 21th century, the conception of a traditional career became a conception of career development experienced by the collaborators and the result of their decisions (S. M. S. Carvalho, 2016). In this way, career management encompasses a project of life, in which the employee himself is responsible. However, companies play a crucial role in career development, supporting their employees (Gallon et al., 2013).

The companies therefore direct their efforts to offer career opportunities, leaving the employees responsible for the development of the same (Hall, 1996). Thus, new success criteria arise for career management, such as: satisfaction with life, the balance between personal and professional life, the development of competencies and the perception of internal and external employability (Bastid \& Bravo, 2013).

Within this new vision, one can perceive that loyalty, commitment and security were valued (Torrington, Hall, \& Taylor, 2002) and nowadays, continuous learning, adaptation to change, commitment to the success of 
the company, as well as its higher productivity are valued. Thus, the psychological contract between employer and employee evolved into a model in which the worker values career management and continuous learning, in contrast, the employer offering conditions for its development (Rousseau, 1989). This caused the psychological contract to become transactional, that is, based on the exchange between the parties (S. M. S. Carvalho, 2016), leading companies to assume a support and development role, rather than control and command (Baruch, 2006).

As far as expatriation is concerned, companies use it as a career development mechanism (Caligiuri, 2000; Evans, Pucik, \& Barsoux, 2002). Studies about the expatriation processes show that employees are, most of the times, satisfied with expatriation, but dissatisfied with the management of their repatriation (Stahl \& Cerdin, 2004; Suutari \& Brewster, 2003; Tung, 1998).

These studies point to the understanding, on the part of expatriates, of expatriation as an opportunity for personal development and career progression. However, this progression may mean abandoning the organization for which they work after the return of international migration, if they feel that the knowledge and competences acquired are not being valued or applied (S. M. S. Carvalho, 2016). Allied to this, studies emphasize the importance of the existence of career plans in companies (Suutari, 2003; Suutari, Tornikoski, \& Mäkelä, 2012).

For Alis et al. (2014), career management is an important tool of the GRH, since it has advantages and benefits for the employee and the company. From the collaborator's perspective, it helps in the progression of professional life, in the improvement of individual capacities and increases the level of employability in a competitive market. From the company's perspective, it enhances the internal development of employees, facilitates substitution in case of exits, reduces employee turnover, decreases the risk of taking advantage of less than the employee can offer, satisfies the collaborator's needs and supports the company's projects and strategies. However, some studies point to the non-development of the career due to lack of support from the company (Stahl, Miller, \& Tung, 2002; Suutari \& Brewster, 2003).

For Selmer (1999), when expatriates perceive that their career expectations are different from the expectations of companies, they are dissatisfied and seek other jobs, outside the company that expatriate, corroborated by the study of Heijden et al. (2009) that demonstrate the intention to abandon the company, when expatriates perceive lack of support, by the company, in his career. However, when the company demonstrates support in career management, expatriates present intent to stay in the company (Lazarova \& Cerdin, 2007). 
In the sporting context, Rodrigues (2010) points out that even brazilian athletes demonstrate wanting to leave Brazil, as management of their careers (51.5\% of respondents), the process of expatriation and career management is troubled. Even with the high wages offered, there is something beyond that, as the cultural adaptation to the site, both the athlete and his family. Moreover, the issue of repatriation of this athlete is something that requires attention and care.

From the above, it is clear that organizations should adopt career management practices within their IHRM strategy, providing success in the expatriation process (Zhou, 2015). According to Guedes (2012), for the employee to have a good career management, it is essential to adapt to the new country. Thus, in the process of expatriation and repatriation, personal and professional adaptations relate to intercultural adaptation.

\section{FINAL CONSIDERATIONS}

Following the objective of this essay, that was to conceptuate the International Human Resources Management (IHRM) and to point out the relationship of such phenomenon with the career management conducted by the person participating in this process of "expatriation", both in the context And in the sporting context, we can observe some notes that literature brings about IHRM and its relationship with career management.

After a review of the literature, it is observed that the IHRM is not a simple process, on the contrary, it is complex, but extremely important and necessary for success. It is important that programs and actions aimed at assisting expatriates, whether in the corporate or sporting context, promote intercultural adjustment as a fundamental part. This means saying that intercultural training is of paramount importance (Tertuliano, Machado, Deustch, et al., 2018).

If previously expected it was that an employee would build his entire career in the same company, with globalization this reality changed. The new work dynamics, where employees change jobs, functions and frequent transfers, including to other countries, is a trend that much resembles the professional athlete, who exchange clubs for many times throughout their careers, not rarely with international passages.

However, apparently the IHRM is better developed in companies, while in sports clubs appears as a secondary concern. Despite the growing professionalization of sport and teams to increasingly adopt entrepreneurial management models, the athlete continues to be understood more as a part of the team than as an employee of a company (Machado, 2013; Tertuliano et al., 2019). Therefore, the expatriate athlete does not receive the necessary attention to the issues and difficulties that this expatriation process 
involves, and may lead him to countless problems of adaptation to the new workplace (Brandão, Magnani, Tega, \& Medina, 2013; Sebben, 2009; Tertuliano, Machado, Oliveira, et al., 2018).

In this context, Tertuliano, Machado, Oliveira et al. (2018) affirm that athletes need to develop some fundamental personal mechanisms to maintain, improve and correct psychological skills and motivation after the expatriation process and the uncertainties it entails, such as strategies of coping. A preparation for athletes leaving their countries or regions should be based on intervention models that prepare them, promoting the training of psychological skills to deal with the new club. In addition, the team that will receive the athlete should also be prepared to welcome him and be aware of the athlete's adaptation period, with the awareness that his athlete's performance may oscillate.

Finally, this essay presents the limitation of being a review study on studies of the corporate area, which limits understanding in this context. In addition, there are few studies on the subject in the sports field, which demonstrates the need for further studies, but directed to the sporting context. However, it is believed that the notes of this essay may contribute to the studies aimed at understanding this phenomenon in the corporate context and also in the sporting context, besides serving as a conceptual basis for companies and clubs that want to plan assertively to the international management of human resources, as well as athletes wishing to have better management of their careers.

\section{REFERENCES}

1. Alis, D., Des Horts, C. H., Chevalier, F., Fabi, B., \& Peretti, J. M. (2014). Gestão dos Recursos Humanos - Uma Abordagem Internacional. Lisboa: Edições Piaget.

2. Altman, Y., \& Baruch, Y. (2012). Global self-initiated corporate expatriate careers: a new era in international assignments? Personnel Review, 41(2), 233-255.

3. Alvito, M. (2006). A parte que te cabe neste latifúndio: O futebol brasileiro e a globalização. Analise Social, 41(179), 451-474.

4. Araujo, B. F. V. B., Teixeira, M. L. M., Cruz, P. B., \& Malini, E. (2012). Adaptação de expatriados organizacionais e voluntários: similaridades e diferenças no contexto brasileiro. Revista de Administração, 47(4), 555-570. https://doi.org/10.5700/rausp1058

5. Arthur, M. B., Claman, P. H., \& DeFillippi, R. J. (1995). Intelligent enterprise, intelligent careers. Academy of Management Perspectives, 9(4), 7-20. https://doi.org/10.5465/AME.1995.9512032185 
6. Arthur, M. B., Hall, D. T., \& Lawrence, B. S. (1989). Generating New Directions in Career Theory: The Case for a Transdisciplinary Approach. In M. B. Arthur, D. T. Hall, \& B. S. Lawrence (Eds.), Handbook of career theory (pp. 7-25). Cambridge: Cambridge University Press.

7. Arthur, M. B., \& Rousseau, D. M. (1996). The Boundaryless Career: A New Employment Principle for a New Organizational Era. New York: Oxford University Press.

8. Arthur, M. B. (2008). Examining contemporary careers: A call for interdisciplinary inquiry. Human Relations, 61(2), 163-186. https://doi.org/10.1177/0018726707087783

9. Arthur, M. B., Khapova, S. N., \& Wilderom, C. P. M. (2005). Career success in a boundaryless career world. Journal of Organizational Behavior, 26(2), 177-202.

10. Baruch, Y. (2006). Career development in organizations and beyond: Balancing traditional and contemporary viewpoints. Human Resource Management Review, 16, 125-138. https://doi.org/10.1016/j.hrmr.2006.03.002

11. Baruch, Y., Dickmann, M., Altman, Y., \& Bournois, F. (2013). Exploring international work: types and dimensions of global careers. The International Journal of Human Resource Management, 24(12), 2369-2393.

12. Bastid, F., \& Bravo, B. (2013). Ter Sucesso na Carreira: Abordagem Conceptual. In A. E. L. Akremi, G. Sylvie, \& J. P. Neveu (Eds.), Comportamento Organizacional: Justiça Organizacional, Expectativas de Carreira e Esgotamento Profissional (2nd ed., pp. 173-202). Lisboa: Instituto Piaget.

13. Bjerregaard, T. (2014). Engaging institutions in global careers: Highly skilled self-initiated expatriates' journeys through a Nordic welfare state. European Management Journal, 32(6), 903-915.

14. Black, J. S., \& Mendenhall, M. (1990). Cross-cultural training effectiveness: a review and theoretical framework for future research. The Academy of Management Review, 15(1), 113-136.

15. Brandão, M. R. F., Magnani, A., Tega, E., \& Medina, J. P. (2013). Além da cultura nacional: o expatriado no futebol. Revista Brasileira de Ciência e Movimento, 21(2), 177-182.

16. Caligiuri, P. M. (2000). Selecting expatriates for personality characteristics: a moderating effect of personality on the relationship between host national contact and cross-cultural adjustment. Management International Review, 40(1), 61-80.

17. Carvalho, M. C., Santos, J. M., \& Brandão, M. L. (2015). Dorsal periaqueductal gray post-stimulation freezing is counteracted by 
neurokinin-1 receptor antagonism in the central nucleus of the amygdala in rats. Neurobiology of Learning and Memory, 121, 5258. https://doi.org/10.1016/j.nlm.2015.04.001

18. Carvalho, S. M. S. (2016). A relação entre a gestão da carreira e a expatriação: um estudo quantitativo com repatriados portugueses. (Masters dissertation). Instituto Politécnico do Porto, Vila do Conde.

19. Chanlat, J. (1995). Quais carreiras e para qual sociedade? Revista de Administração de Empresas, 35(6), 67-75. https://doi.org/10.1590/S0034-75901995000600008

20. Chien, T. C., \& Mclean, G. N. (2011). Intercultural training for US business expatriates in Taiwan. Journal of European Industrial Training, 35(9), 858-873.

21. Damo, A. S. (2007). Do dom à profissão: a formação de futebolistas no Brasil e na França. São Paulo: Hucitec.

22. DeFillippi, R. J., \& Arthur, M. B. (1994). The boundaryless career: A competency-based perspective. Journal of Organizational Behavior, 15(4), 307-324.

23. Derr, C. B. (1986). Managing the New Careerists: The Diverse Career Success Orientations of Today's Workers. Wokingham: Jossey-Bass.

24. Dowling, P. J., Festing, M., \& Engle, A. D. (2008). International human resource management: Managing people in a multinational context (5th ed.). Cengage Learning.

25. Evans, P., Pucik, V., \& Barsoux, J. L. (2002). The Global Challenge-Frameworks for International Human Resource Management. New York: McGraw-Hill.

26. Ferreira, A. F. G. (2015). Motivações dos expatriados qualificados que se deslocam de países desenvolvidos para países em desenvolvimento. (Masters dissertation). Universidade do Porto, Porto.

27. Gallon, S., Scheffer, A. B. B., \& Bitencourt, B. M. (2013). "Eu fui, voltei e ninguém viu": um estudo sobre a expectativa de carreira após a repatriação em uma empresa brasileira. Cadernos EBAPE.BR, 11(1), 128-148.

28. Guedes, B. M. D. (2012). Stresse Em Expatriados - Transpor As Fronteiras De Si -. Universidade Lusófona de Humanidades e Tecnologias, Lisboa.

29. Hall, D. T. (1996). Careers Protean Century of the. Academy of Management Executive, 10(4), 8-16.

30. Heijden, J. A., Engen, M. L., \& Paauwe, J. (2009). Expatriate career support: predicting expatriate turnover and performance. The 
International Journal of Human Resource Management, 20(4), 831-845.

31. Hill, C. (2005). International Business: Competing in the Global Marketplace. New York: McGraw-Hill.

32. Ivancevich, J. M. (2008). Gestão de Recursos Humanos (10th ed.). São Paulo: McGraw-Hill.

33. Kanter, R. M. (1989). Careers and the Wealth of Nations: A MacroPerspective on the Structure and Implications of Career Forms. In M B Arthur, D. T. Hall, \& B. S. Lawrence (Eds.), Handbook of career theory (pp. 506-521). Cambridge: Cambridge University Press.

34. Lazarova, M. B., \& Cerdin, J.-L. (2007). Revisiting repatriation concerns: organizational support versus career and contextual influences. Journal of International Business Studies, 38(3), 404429.

35. Levinson, D. J. (1986). A conception of adult development. American Psychologist, 41(1), 3-13.

36. Mach, M., \& Baruch, Y. (2015). Team performance in cross cultural project teams: The moderated mediation role of consensus, heterogeneity, faultlines and trust. Cross Cultural Management, 22(3), 464-486.

37. Machado, F. S. (2013). Gestão de pessoas interncional no contexto esportivo brasileiro: uma análise dos processos de expatriação e repatriação de jogadores em um clube de futebol gaúcho. (Masters dissertation). Universidade Federal do Rio Grande do Sul, Porto Alegre.

38. Marconi, M. A., \& Lakatos, E. M. (2017). Metodologia Cientifica (7th ed.). São Paulo: Atlas.

39. Moore, C., Gunz, H., \& Hall, D. (2007). Tracing the Historical Roots of Career Theory in Management and Organizational Studies. In H. Gunz \& M. Peiperl (Eds.), Handbook of Career Studies (pp. 13-28). Thousand Oaks: Sage.

40. Nardi, L. M. R. (2015). O perfil do profissional auto-expatriado e a percepção de gestores de recursos humanos sobre este perfil. (Masters dissertation). Universidade Católica do Rio Grande do Sul, Porto Alegre.

41. Pereira, C. F., \& Saboia, J. (2015). O processo de expatriação de executivos globais: o estudo de caso da Lanxess S/A. Revista Escola de Negócios, 3(2), 1-14.

42. Pontes, V. S., Ribeiro, C. H. V., Garcia, R. M., \& Pereira, E. G. B. (2018). Migração no Voleibol brasileiro: a perspectiva de atletas e treinadores de alto rendimento. Movimento, 24(1), 187-198. 
43. Rego, A., \& Cunha, M. P. (2009). Manual de Gestão Transcultural de Recursos Humanos. Lisboa: RH Editora.

44. Rial, C. (2003). Futebol e mídia: a retórica televisiva e suas implicações na identidade nacional, de gênero e religiosa. Antropolítica, 14(2), 61-80.

45. Rial, C. (2008). Rodar: a circulação dos jogadores de futebol brasileiros no exterior. Horizontes Antropológicos, 14(30), 21-65.

46. Riesenberger, J. R., Knight, G., \& Cavusgil, S. T. (2010). Negócios internacionais: estratégia, gestão e novas realidades. São Paulo: Pearson Education BR.

47. Rodrigues, F. X. F. (2010). O fim do passe e as transferências de jogadores Brasileiros em uma época de globalização. Sociologias, 12(24), 338-380.

48. Rousseau, D. M. (1989). Psychological and implied contracts in organizations. Employee Responsibilities and Rights Journal, 2(2), 121-139.

49. Santos, G. G. (2011). Desenvolvimento de Carreira: Uma análise centrada na relação entre o trabalho e a família. Lisboa: Editora $\mathrm{RH}$.

50. Schein, E. H. (1978). Career Dynamics: Matching Individual and Organizational Needs. Reading: Addison-Wesley.

51. Sebben, A. (2009). O preparo do atleta de futebol. Retrieved May 17, 2015, from http://universidadedofutebol.com.br/andreasebben-psicologa-parte-1/

52. Selmer, J. (1999). Career issues and international adjustment of business expatriates. Career Development International, 4(2), 7787.

53. Shen, Y., \& Kram, K. E. (2011). Expatriates developmental networks: network diversity, base, and support functions. Career Development International, 16(6), 528-552.

54. Silva, D. V., Rigo, L. C., \& Freitas, G. S. (2012). Considerações sobre a migração, a naturalização e a dupla cidadania de jogadores de futebol. Revista Da Educação Física Da UEM, 23(3), 457-468. https://doi.org/10.4025/reveducfis.v23i3.15381

55. Stahl, G K, Miller, E. L., \& Tung, R. L. (2002). Toward a Boundaryless Career: A Closer Look at the Expatriate Career Concept and the Perceived Implications of an International Assignment. Journal of World Business, 37, 216-227.

56. Stahl, G. K, \& Cerdin, J. L. (2004). Global careers in French and German multinational corporations. Journal of Management Development, 23(9), 885-902.

57. Super, D. E. (1957). The Psychology of Careers. New York: Harper 
\& Row.

58. Super, D. E. (1990). The Life Span, Life Space Approach to Career Development. In D. Brown \& L. Brooks (Eds.), Carrer Choice and Development (pp. 197-261). San Francisco: Jossey-Bass.

59. Suutari, V. (2003). Global managers: career orientation, career tracks, life-style implications and career commitment. Journal of Managerial Psychology, 18(3), 185-207.

60. Suutari, V., \& Brewster, C. (2003). Repatriation: empirical evidence from a longitudinal study of careers and expectations among finnish expatriates. International Journal of Human Resource Management, 14(7), 1132-1151.

61. Suutari, V., Tornikoski, C., \& Mäkelä, L. (2012). Career decision making of global careerists. The International Journal of Human Resource Management, 23(16), 3455-3478. https://doi.org/10.1080/09585192.2011.639026

62. Tertuliano, I. W., Oliveira, V., Pavlović, V., \& Machado, A. A. (2018). The need for expatriation and the planning of the process: Organizational looks for sports. Ekonomski Pogledi, 20(1), 1-17.

63. Tertuliano, I. W. (2016). Processo de expatriação de voleibolistas: Concepções Bioecológicas. (Doctoral Thesis).Universidade Estadual Paulista, Rio Claro.

64. Tertuliano, I. W. (2018). Expatriados e atletas nômades. In F. Rebustini \& A. A. Machado (Eds.), Vulnerabilidade no Esporte: Volume 2 (1st ed., pp. 57-74). Jundiaí: Paco.

65. Tertuliano, I. W., Machado, A. A., Deustch, S., Montiel, J. M., \& Bartholomeu, D. (2018). Motivos e intenções para expatriação de voleibolistas. Revista de Administração Contemporânea, 22(4), 531-551.

66. Tertuliano, I. W., Machado, A. A., Oliveira, V., Montiel, J. M., Bartholomeu, D., \& Deutch, S. (2018). Athletic expatriation and volleyball: adaptation to the new club. Manual Therapy, Posturology \& Rehabilitation Journal, 16(626), 1-8.

67. Tertuliano, I. W., Montiel, J. M., Deutsch, S., \& Machado, A. A. (2019). Considerações em relação a expatriação e Globalização: Interfaces com aspectos emocionais. Revista Inteligência Competitiva, 9(1), 15-30.

68. Tiesler, N. C. (2016). Three types of transnational players: differing women's football mobility projects in core and developing countries. Revista Brasileira de Ciências Do Esporte, 38(2), 201210. https://doi.org/10.1016/j.rbce.2016.02.015

69. Torrington, D., Hall, L., \& Taylor, S. (2002). Human Resource Management. Harlow: Prentice Hall. 
Expatriates and international career management: corporate and sporting...

70. Tung, R. L. (1998). American expatriates abroad: From neophytes to cosmopolitans. Journal of World Business, 33(2), 125-144.

71. Wentland, D. M. (2003). A New Practical Guide for Determining Expatriate Compensation: The Comprehensive Model. Compensation \& Benefits Review, 35(3), 45.

72. Zhou, Y. (2015). The Career Path of Expatriates at Repatriation. Journal of Economics, Business and Management, 3(5), 548-553. https://doi.org/10.7763/JOEBM.2015.V3.244

Рад је примљен: 05.10.2019.

Рад је прихваћен за итампање: 01.11.2019. 